\title{
ÚNG DỤNG CÔNG NGHỆ GIS THÀNH LẬP BẢN ĐỒ THOÁI HÓA ĐẤT TIỀM NĂNG VÙNG TÂY NGUYÊN
}

\author{
TS. LƯU THẾ ANH, ThS. NGUYẼ̃N NGỌC THÀNH, KS. HOÀNG QUÓC NAM
}

Viện Địa lý - Viện Hàn Lâm Khoa học và Công nghệ Việt Nam

\section{Tóm tắt:}

Bản đồ thoái hóa đất tiềm năng là một dạng bản đồ chuyên đề trong hệ thống bản đồ địa lý. Bản đồ thoái hóa đất tiềm năng có ý nghĩa và vai trong quan trọng trong việc quản lý và định hướng sử dụng hợp lý tài nguyên đất. Bài báo này trình bày tóm tắt các bước trong quy trình ứng dụng công nghệ GIS thành lập bản đồ thoái hóa đất tiềm năng vùng Tây Nguyên tỷ lệ 1:250.000 trên quan điểm địa lý tổng hợp. Trên bản đồ thành quả thể hiện quy mô phân bố của 4 cấp thoái hóa đất tiềm năng khác nhau, trong đó cấp tiềm năng thoái hóa nhẹ (TN1) có 1.528.933,0 ha (chiếm 28\% tổng diện tích tự nhiên toàn vùng); cấp tiềm năng thoái hóa trung bình (TN2) có 2.059.142, 8 ha (chiếm 37,7\%); cấp tiềm năng thoái hóa mạnh (TN3) có 1.159.188,9 ha (chiếm 21,2\%) và cấp tiềm năng thoái hóa rất mạnh (TN4) có $716.707,4$ ha (chiếm 13,1\%). Kết quả nghiên cứu đã cung cấp những thông tin cơ bản về tiềm năng thoái hóa đất, phục vụ cho công tác lập quy hoạch sử dụng đất và đề xuất các giải pháp sử dụng đất hợp lý vùng Tây Nguyên.

\section{Mỏ đầu}

Thoái hóa đất là vấn đề môi trường cấp bách mà nhiều quốc gia đang phải đối mặt hiện nay. Thuật ngữ "thoái hóa đất" sử dụng để nói đến sự suy giảm độ phì đất, biểu hiện ở đặc tính xấu như: cấu trúc bị phá vỡ, suy giảm chất dinh dưỡng dẫn đến mất một phần hoặc mất hoàn toàn khả năng sản xuất của đất, làm giảm năng suất cây trồng và ảnh hưởng nghiêm trọng đến môi trường sinh thái $[6,8]$. Thoái hóa đất là nguyên nhân chính dẫn đến hoang mạc hóa ở các vùng khô hạn, bán khô hạn và vùng ẩm nửa khô hạn do các nguyên nhân khác nhau, trong đó có biến đổi khí hậu và các hoạt động của con người gây ra [11]. Hàng năm, trên thế giới có khoảng 11 - 13 triệu hécta rừng bị chặt phá, dẫn đến hàng chục triệu hécta đất bị thoái hóa, tác động đến cuộc sống của khoảng 250 triệu người [12]. Trong bối cảnh biến đổi khí hậu diễn biến phức tạp, các quá trình thoái hóa đất ngày càng lan rộng trên phạm vi toàn cầu. Khoảng $30 \%$ diện tích bề mặt Trái đất là hoang mạc hoặc đang diễn ra quá trình hoang mạc hóa, trong đó khoảng 1.964 triệu hécta đất bị thoái hóa do nhân tác ở các mức độ từ nhẹ đến rất nặng [9]. Trước tình hình đó, UNEP đã kêu gọi cần nghiên cứu ngăn ngừa thoái hoá đất và hoang mạc hoá ở mỗi quốc gia và toàn cầu. Sự thành công trong ứng phó với thoái hóa đất đòi hỏi phải hiểu rõ những nguyên nhân, tác động và mức độ thoái hóa đất trong mối liên hệ với các yếu tố khí hậu, thổ nhưỡng, nước, thực vật và hoạt động kinh tế - xã hội [10]. Trên thế giới đã xây dựng bản đồ thoái hóa đất ở các tỷ lệ khác nhau: quy mô toàn cầu tỷ lệ 1/10.000.000 [8]; vùng Nam Phi và Trung Cận Đông, Nam và Đông Nam Á tỷ lệ 1:5.000.000 [5, 9]; vùng Mỹ La Tinh tỷ lệ 1:1.000.000 [8]; vùng Trung và Đông Âu tỷ lệ $1: 2.500 .000$ [6] và tỷ lệ lớn hơn cho cấp quốc gia [11]. Các nghiên cứu đã thống nhất 
phân mức độ thoái hóa làm 4 cấp: nhẹ, trung bình, mạnh, rất mạnh.

Ở nước ta, thoái hoá đất là xu thế chung ở các vùng sinh thái. Các quá trình xói mòn, rửa trôi, trượt lở đất, xâm nhập mặn, cát bay, cát chảy, khô hạn và hoang mạc hóa đang diễn ra phổ biến với tốc độ nhanh [1]. Từ thực tế nghiên cứu tổng hợp đất bazan thoái hoá ở Tây Nguyên giai đoạn 1984 1987 [3] và giai đoạn 2004 - 2005 [4] cho thấy, vùng Tây Nguyên đã và đang xảy ra các quá trình thoái hóa đất mạnh mẽ do các quá trình tự nhiên và nhân tác đan xen nhau, một số dạng hoang mạc hóa đã xuất hiện cục bộ, ảnh hưởng nghiêm trọng đến độ phì đất, năng suất cây trồng, môi trường sinh thái và đe dọa sản xuất nông nghiệp. Mặt khác, tình hình hạn hán kéo dài vào mùa khô, lũ lụt vào mùa mưa đã làm gia tăng các quá trình thoái hóa đất. Chính phủ đã chỉ rõ, Tây Nguyên là một trong bốn vùng ưu tiên chống sa mạc hoá cấp bách [2]. Để quản lý và sử dụng tài nguyên đất vùng Tây Nguyên hiệu quả, việc nghiên cứu xây dựng bản đồ thoái hóa đất tiềm năng là yêu cầu cần thiết về khoa học và có ý nghĩa thực tiễn hiện nay.

\section{Dữ liệu sử dụng và phương pháp nghiên cứu}

\subsection{Dũr liệu sử dụng}

- Lượng mưa và lượng bốc hơi của 16 Trạm đo (Pleiku, Đắk Tô, An Khê, Kon Tum, Ayunpa, Ea Kmat, Buôn Mê Thuộc, Buôn Hồ, M’Đrắk, Đắk Nông, Đà Lạt, Liên Khương, Bảo Lộc, Lắk, Yaly, Đắk Mil) do Trung tâm Khí tượng Thủy văn Quốc gia cung cấp.

- Bản đồ địa hình Tây Nguyên tỷ lệ 1:250.000 thu thập tại Trung tâm Thông tin dữ liệu đo đạc và bản đồ (Cục Đo đạc và Bản đồ - Bộ TN\&MT). Bản đồ địa chất khoáng sản tỷ lệ 1:200.000 gồm các mảnh Bà Nà, Đắk Tô, Quảng Ngãi, Kon Tum, Măng Đen - Bồng Sơn, Pleiku, An Khê, Bản
Đôn, Buôn Ma Thuột, Bu Prang, Bến Khế, B'Lao, Đà Lạt - Cam Ranh và Phan Thiết do Cục Địa chất và Khoáng sản lập năm 1996. Bản đồ vỏ phong hóa Tây Nguyên là kết quả của Chương trình Tây Nguyên II (1984 1988).

- Bản đồ đất Tây Nguyên tỷ lệ 1:250.000 do Viện Quy hoạch và Thiết kế Nông nghiệp thành lập năm 1998. Bản đồ địa mạo tỷ lệ 1:250.000 và kết quả phân tích các mẫu đất do Đề tài TN3/T01 (Chương trình Tây Nguyên 3) thực hiện năm 2013.

\subsection{Phương pháp nghiên cứu}

- Khảo sát thực địa: Tổ chức các chuyến khảo sát qua các mặt cắt địa hình để ghi nhận các dạng thoái hóa đất ngoài thực địa và đào phẫu diện đất đại diện cho các loại đất chính ở Tây Nguyên. Lấy mẫu đất phục vụ phân tích các tính chất hóa lý đất.

- Thành lập bản đồ xói mòn tiềm năng: Sử dụng phương trình mất đất phổ dụng của Wischmeier và Smith $(1958,1978)$. Công thức như sau:

$$
A=R^{*} K^{*} L^{*} S^{*} C^{*} P
$$

Trong đó, $A$ là lượng đất mất trung bình do xói mòn (tấn/ha/năm); $\mathrm{R}$ là chỉ số xói mòn của mưa; $L$ là chỉ số chiều dài sườn dốc; S là chỉ số độ dốc; K là chỉ số kháng xói của đất; $C$ là chỉ số lớp phủ thực vật; $P$ là chỉ số bảo vệ đất của các biện pháp chống xói mòn.

- Thành lập bản đồ thoái hóa đất tiềm năng: Tiềm năng thoái hóa đất được chia ra 4 cấp: Tiềm năng thoái hóa nhẹ (TN1); trung bình (TN2); mạnh (TN3) và rất mạnh (TN4). Sử dụng thuật toán trung bình cộng trong phần mềm ArcGIS tính toán với công thức như sau:

$\mathrm{TN}=$ ROUND (InRas1 + InRas2 + $\ln \operatorname{Ras} 3+\ldots+\operatorname{InRasn}) / n$

Trong đó, TN là cấp thoái hóa đất tiềm năng; InRas1, InRas2, InRas3 và InRasn là 
các chỉ tiêu đầu vào ở dạng dữ liệu raster. Hệ thống 4 tiêu chí gồm 9 chỉ tiêu được lựa chọn ở Bảng 1. (Xem bảng 1, hình 1)

\section{Kết quả và thảo luận}

3.1. Phân cấp các chỉ tiêu cho xây dựng bản đồ thoái hóa đất tiềm năng vùng Tây Nguyên

- Chỉ tiêu đá mẹ: Thành phần và tính chất hóa học của đá mẹ quyết định tính chất của đất phát sinh. Tây Nguyên có nền địa chất phức tạp, gồm các loại đá macma phun trào và xâm nhập, đá biến chất, trầm tích bở rời và dốc tụ. Vùng có đá bazan tuổi Pliocen Pleistocen sớm thường xuất hiện tầng bôxit và laterit dày, tạo ra mặt chắn địa hóa ngăn cách mối liên hệ giữa đá mẹ và các tầng đất. Phân chia chỉ tiêu đá mẹ cho đánh giá thoái hóa đất tiềm năng như sau: (Xem bảng 2)

- Chỉ tiêu vỏ phong hóa: Vỏ phong hóa có mối quan hệ mật thiết với thành phần khoáng vật của đá gốc, mỗi kiểu vỏ phong hóa ảnh hưởng khác nhau đến các quá trình thoái hóa đất. Vỏ phong hóa được phân loại cho đánh giá thoái hóa đất tiềm năng như sau: (Xem bảng 3)

- Chỉ tiêu độ dày tầng đất: Độ dày tầng đất có ý nghĩa đặc biệt quan cho sản xuất nông nghiệp. Chỉ tiêu độ dày tầng đất của phẫu diện dùng đánh giá mức độ xói mòn và đánh giá tiềm năng đất đai, điều kiện lập địa. Nơi có tầng đất mỏng, xuất hiện đá lộ đầu phản ánh quá trình xói mòn xảy ra mạnh. (Xem bảng 4)

- Chỉ tiêu dạng địa hình: Mỗi dạng địa hình phát sinh là các yếu tố tiền đề có vai trò quan trọng và ảnh hưởng đến các quá trình thoái hóa đất. Vì vậy, được phân loại để thành lập bản đồ thoái hóa đất tiềm năng vùng Tây Nguyên như sau: (Xem bảng 5)

Bảng 1: Các tiêu chí và chỉ tiêu xây dựng bản đồ thoái hóa đất tiềm năng

\begin{tabular}{|c|c|c|c|}
\hline STT & Tiêu chí & Chỉ tiêu & Phương pháp xác định và tính toán \\
\hline & \multirow{3}{*}{$\begin{array}{c}\text { Đá me, vỏ phong } \\
\text { hóa và thổ } \\
\text { nhưỡng }\end{array}$} & 1. Loại đá mẹ & Triết tách và phân cấp từ bản đồ địa chất \\
\hline & & 2. Vỏ phong hóa & Triết tách và phân cấp từ bản đồ vỏ phong hóa \\
\hline & & 3. Độ dày tầng đất & Triết tách và phân cấp từ bản đồ đất \\
\hline & \multirow{3}{*}{ Địa hình } & 1. Dạng địa hình & Triết tách và phân cấp trên cơ sở bản đồ địa mạo \\
\hline & & 2. Độ dốc địa hình & Tính toán và phân cấp từ mô hình số độ cao \\
\hline & & 3. Độ cao địa hình & Tính toán và phân cấp từ mô hình số độ cao \\
\hline & \multirow[t]{2}{*}{$\begin{array}{l}\text { Khí hậu và } \\
\text { thủy văn }\end{array}$} & 7. Mức độ khô hạn & $\begin{array}{l}\text { Sử dụng số liệu lượng mưa và lượng bốc hơi } \\
\text { trung bình tháng của các Trạm Khí tượng Thủy } \\
\text { văn từ năm } 1980 \text { - } 2010\end{array}$ \\
\hline & & 8. Mật độ sông suối & Triết tách và phân cấp từ mô hình số độ cao \\
\hline 4 & $\begin{array}{l}\text { Xói mòn tiềm } \\
\text { năng }\end{array}$ & $\begin{array}{l}\text { 9. Mức độ xói mòn } \\
\text { tiềm năng }\end{array}$ & $\begin{array}{l}\text { Sử dụng phương trình mất đất phổ dụng của } \\
\text { Wischmeier và Smith để tính toán }\end{array}$ \\
\hline
\end{tabular}

Nguồn: Lưu Thế Anh, 2012 [1] 


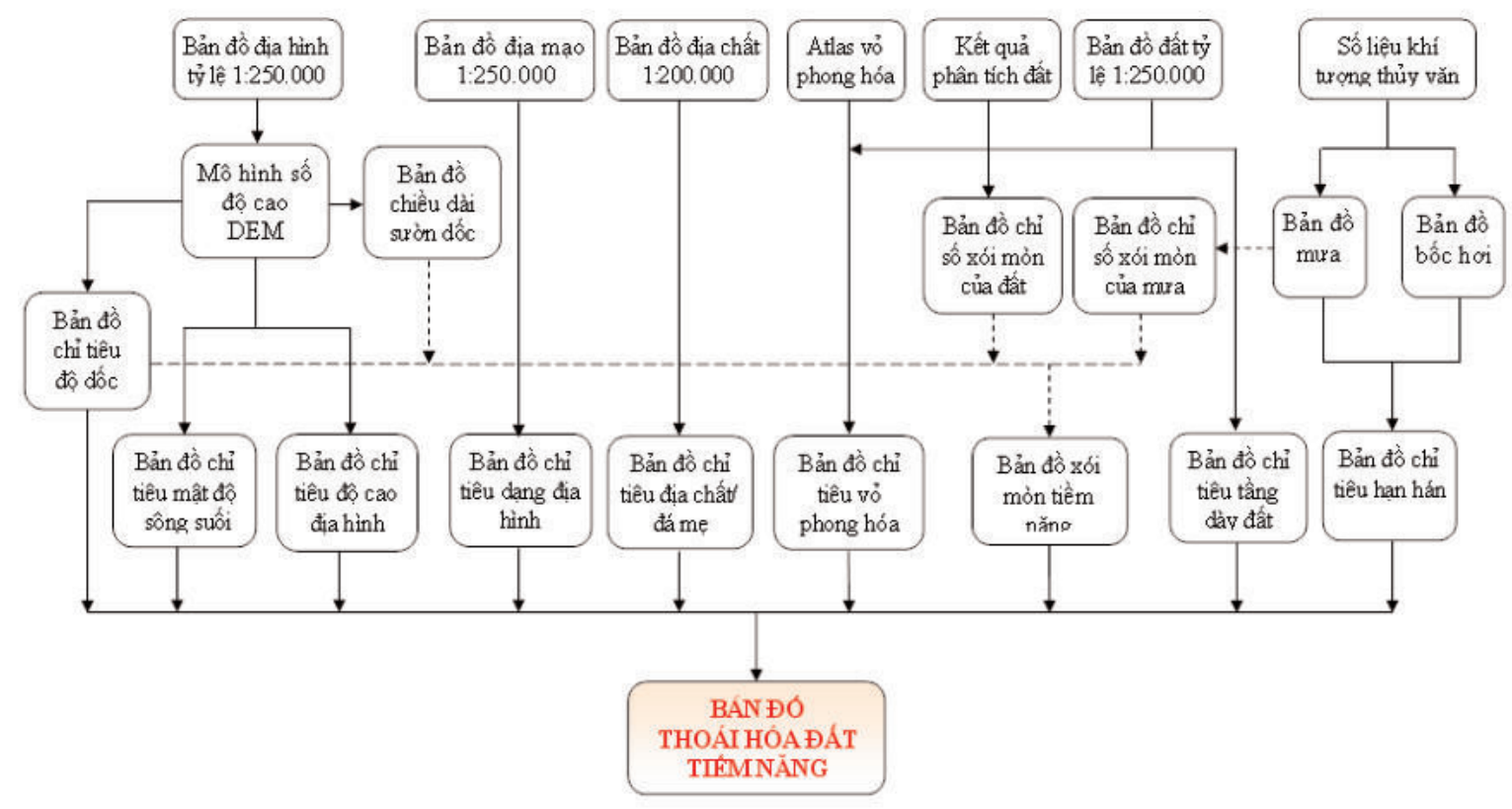

Hình 1: Quy trình thành lập bản đồ thoái hóa đất tiềm năng vùng Tây Nguyên bằng công nghệ GIS

Bảng 2: Phân loại đá mẹ/mẫu chất cho đánh giá thoái hóa đất tiềm năng

\begin{tabular}{|c|l|c|c|}
\hline STT & \multicolumn{1}{|c|}{ Loại đá mẹ/mẫu chất } & Ký hiệu & Mức độ thoái hóa \\
\hline 1 & $\begin{array}{l}\text { - Nhóm đá bazan tuổi Pleistocen giữa }\left(\mathrm{Q}_{1}{ }^{2}\right) \\
- \text { Nhóm trầm tích bở rời phù sa và dốc tụ }(\mathrm{Q})\end{array}$ & I & Yếu \\
\hline 2 & $\begin{array}{l}\text { - Nhóm đá macma xâm nhập và đá biến chất } \\
- \text { Nhóm đá trầm tích lục nguyên }\end{array}$ & II & Trung bình \\
\hline 3 & $\begin{array}{l}\text { Nhóm đá bazan tuổi Pliocen - Pleistocen sớm }\left(\mathrm{N}_{2}-\mathrm{Q}_{1}{ }^{1}\right) \text { có } \\
\text { tầng laterit }\end{array}$ & III & Mạnh \\
\hline 4 & $\begin{array}{l}\text { Nhóm đá bazan tuổi Pliocen - Pleistocen sớm }\left(\mathrm{N}_{2}-\mathrm{Q}_{1}{ }^{1}\right) \text { có } \\
\text { tầng bôxit }\end{array}$ & IV & Rất mạnh \\
\hline
\end{tabular}


Bảng 3: Phân loại kiểu vỏ phong hóa cho đánh giá thoái hóa tiềm năng

\begin{tabular}{|c|l|c|c|}
\hline STT & \multicolumn{1}{|c|}{ Kiểu vỏ phong hóa } & Ký hiệu & Mức độ thoái hóa \\
\hline 1 & $\begin{array}{l}\text { Vỏ phong hóa alferit (AIFe) trên đá bazan Pleistocen giữa } \\
\left(\beta Q_{1}{ }^{2}\right) \\
\text { Vỏ phong hóa saprolit (Sa) }\end{array}$ & I & Yếu \\
\hline 2 & Vỏ phong hóa silicit (Si) & II & Trung bình \\
\hline 3 & Vỏ phong hóa sialit (SiAl) & III & Mạnh \\
\hline 4 & $\begin{array}{l}\text { Vỏ phong hóa sialferit (SiAlFe) } \\
\text { Vỏ phong hóa ferosialit (Fesial) } \\
\text { Vỏ phong hóa feralit (FeAl) } \\
\text { Vỏ phong hóa alferit (AlFe) trên đá phun trào bazan } \\
\text { Pliocen - Pleistocen sớm ( }\left(\mathrm{N}_{2}-\mathrm{Q}_{1}{ }^{1}\right)\end{array}$ & IV & Rất mạnh \\
\hline
\end{tabular}

Bảng 4: Phân loại độ dày tầng đất cho đánh giá thoái hóa đất tiềm năng

\begin{tabular}{|c|c|c|c|}
\hline STT & Tầng dày đất & Ký hiệu & Mức độ thoái hóa \\
\hline 1 & $>100 \mathrm{~cm}$ & I & Yếu \\
\hline 2 & $50-100 \mathrm{~cm}$ & II & Trung bình \\
\hline 3 & $30-50 \mathrm{~cm}$ & III & Mạnh \\
\hline 4 & $<30 \mathrm{~cm}$ & IV & Rất mạnh \\
\hline
\end{tabular}


Bảng 5: Phân loại chỉ tiêu dạng địa hình cho đánh giá thoái hóa đất tiềm năng

\begin{tabular}{|c|c|c|c|}
\hline STT & Dạng địa hình & Ký hiệu & \begin{tabular}{|c} 
Mức độ \\
thoái hóa
\end{tabular} \\
\hline 1 & 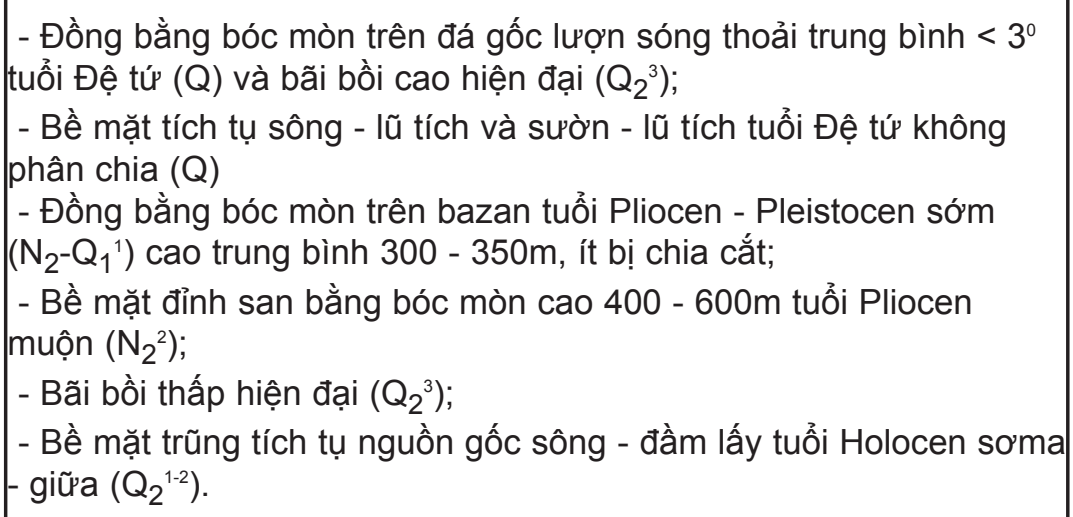 & I & Yếu \\
\hline 2 & $\begin{array}{l}\text { - Thềm sông bậc I tích tụ và xâm thực trên đá gốc tuổi Holicen } \\
\text { sớm - giữa }\left(\mathrm{Q}_{2}{ }^{1-2}\right) \\
\text { - Thềm sông bậc II tích tụ và xâm thực trên đá gốc tuổi Pleistocen } \\
\text { muộn }\left(\mathrm{Q}_{1}{ }^{3}\right) ; \\
\text { - Đồng bằng bóc mòn trên bzan tuổi Pliocen - Pleistocen sớm }\left(\mathrm{N}_{2}{ }^{-}\right. \\
\left.\mathrm{Q}_{1}{ }^{1}\right) ; \\
\text { - Bề mặt cao nguyên bazan tuổi Pleistocen giữa }\left(\mathrm{Q}_{1}{ }^{2}\right) \text { cao trung } \\
\text { bình } 700-800 \mathrm{~m} \text { bị chia cắt yếu. }\end{array}$ & II & Trung bình \\
\hline 3 & $\begin{array}{l}\text { - Chóp và miệng núi lửa; } \\
\text { - Sườn bó̀c mòn rửa trôi tuổi Đệ tứ không phân chia }(Q) \text {; } \\
\text { - Đồng bằng tích tụ - bóc mòn trên đá bazan tuổi Pleistocen giữa } \\
\left(Q_{1}{ }^{2}\right) \text {. }\end{array}$ & III & Mạnh \\
\hline 4 & $\begin{array}{l}\text { - Núi sót bóc mòn trên đá gốc và khe rãnh và đáy trũng xâm thực } \\
\text { tuổi Đệ tứ }(\mathrm{Q}) \text {; } \\
\text { - Bề mặt đỉnh san bằng bóc mòn cao } 800-1.000 \mathrm{~m} \text { tuổi Pliocen } \\
\text { sớm }\left(\mathrm{N}_{2}{ }^{1}\right) \text { và cao } 1.200-1.400 \mathrm{~m} \text { tuổi Miocen muộn }\left(\mathrm{N}_{1}{ }^{3}\right) \text {; } \\
\text { - Bề mặt cao nguyên bazan tuổi Pliocen - Pleistocen sớm }\left(\mathrm{N}_{2} \text { - }\right. \\
\left.\mathrm{Q}_{1}{ }^{1}\right) \text { cao trung bình } 600-800 \mathrm{~m} \text { bị chia cắt mạnh; } \\
\text { - Bề mặt đỉnh san bằng bóc mòn cao } 1.600-2.000 \mathrm{~m} \text { tuổi Miocen } \\
\text { sớm }\left(\mathrm{N}_{1}{ }^{1}\right) \text { và Miocen giữa }\left(\mathrm{N}_{1}{ }^{2}\right) \text {; } \\
\text { - Vách và sườn bóc mòn, sườn trọng lực, sườn xâm thực tuổi Đệ } \\
\text { tứ không phân chia }(\mathrm{Q}) \text {. }\end{array}$ & IV & Rất mạnh \\
\hline
\end{tabular}


- Chỉ tiêu độ dốc địa hình: Độ dốc địa hình và chiều dài sườn dốc ảnh hưởng và chi phối đến các quá trình xói mòn và rửa trôi bề mặt. Khi nghiên cứu định lượng xói mòn đất do mưa. Trong hướng dẫn đánh giá tiềm năng đất đai của $\mathrm{FAO}$ chỉ tiêu độ dốc được phân thành 4 cấp. Vì vâyy, chỉ tiêu độ dốc địa hình được sử dụng để đánh giá thoái hóa đất tiềm năng cho vùng Tây Nguyên với các cấp như sau: (Xem bảng 6)

- Chỉ tiêu độ cao địa hình: Độ cao địa hình ảnh hưởng đến các quá trình tàn tích và tích tụ các ôxit của $\mathrm{Fe}, \mathrm{Al}$ theo dòng nước di chuyển lên xuống theo chiều thẳng đứng trong phẫu diện đất. Khi nghiên cứu đặc trưng địa lý phát sinh và thoái hóa đất bazan ở Tây Nguyên, Nguyễn Đình Kỳ (1990) đã chỉ rõ, có một giới hạn về độ cao đáng chú ý, những khu vực có độ cao trên $700 \mathrm{~m}$ có thoái hóa tiềm năng mạnh hơn các khu vực có độ cao dưới 700 m [3]. Như vậy, đối với chỉ tiêu độ cao địa hình được đề xuất sử dụng và phân chia như sau: (Xem bảng 7)

- Chỉ tiêu khô hạn: Mức độ khô hạn được tính từ tỷ số lượng mưa chia cho lượng bốc hơ tiềm năng đã được $F A O$ đề xuất sử dụng để đánh giá nguy cơ xuất hiện hoang mạc hóa. Tỷ số này bằng 1 là bắt đầu xuất hiện hạn, từ $0,05-0,65$ là xuất hiện hoang mạc. Đối với Tây Nguyên, độ dài mùa khô (những tháng có lượng mưa $<100 \mathrm{~mm}$ ) và số tháng kiệt (những tháng có lượng mưa < $25 \mathrm{~mm}$ ) sử dụng cho đánh giá và được phân cấp như sau: (Xem bảng 8)

- Chỉ tiêu mật độ sông suối: Khi xây dựng bản đồ thoái hóa đất tiềm năng của Bhutan, Moe Myint và Pema Thinley (2006) cho rằng, mật độ sông suối là nhân tố quan trọng gây thoái hóa đất thông qua xói mòn và rửa trôi [7] và được phân cấp như sau: (Xem bảng 9)

- Tiêu chí xói mòn tiềm năng: Xói mòn tiềm năng phản ánh khả năng xảy ra quá trình thoái hóa đất do xói mòn bề mặt [1].
Mức độ xói mòn tiềm năng được dụng để thành lập bản đồ thoái hóa đất tiềm năng vùng Tây Nguyên. (Xem bảng 10)

3.2. Kết quả xây dựng bản đồ thóa hóa đất tiềm năng vùng Tây Nguyên

Kết quả xây dựng bản đồ thoái hóa đất tiềm năng vùng Tây Nguyên tỷ lệ 1:250.000 cho thấy quy mô các cấp thoái hóa như sau:

- Tiềm năng thoái hóa nhẹ (TN1): Diện tích thoái hóa tiềm năng nhẹ vùng Tây Nguyên có $1.528 .933,0$ ha (chiếm $28 \%$ tổng diện tích tự nhiên). Trong đó tỉnh Đắk Lắk có diện tích lớn nhất (456.997,4 ha); tiếp đến tỉnh Gia Lai: 357.386,7 ha; tỉnh Đắk Nông có 237.291,2 ha; tỉnh Lâm Đồng có 218.099,9 ha. Trên bản đồ thoái hóa đất tiềm năng tỷ lệ 1:250.000 của vùng cho thấy, những diện tích thoái hóa tiềm năng nhẹ chủ yếu trên các loại đất hình thành trên sản phẩm phong hóa của đá bazan tuổi Pleistocen giữa $\left(Q_{1}{ }^{2}\right)$ hoặc loại đất xám trên đá macma xâm nhập và sản phẩm dốc tụ có tầng đất dày thường $>100 \mathrm{~cm}$, địa hình bằng phẳng, độ cao trung bình dưới $500 \mathrm{~m}$. Những khu vực này đang được khai thác trồng cây công nghiệp dài ngày và còn duy trì thảm thực vật rừng tự nhiên.

- Tiềm năng thoái hóa trung bình (TN2): Diện tích thoái hóa tiềm năng trung bình toàn vùng có 2.059.142,8 ha (chiếm $37,7 \%)$. Trong đó, tỉnh Đắk Lắk có diện tích lớn nhất khoảng 694.649,4 ha; tiếp đến tỉnh Gia Lai có 553.926,4 ha; tỉnh Đắk Nông có $286.841,0$ ha; tỉnh Kon Tum có 267.554,7 ha và tỉnh Lâm Đồng có 256.171,4 ha. Các đơn vị bản đồ có mức độ thoái hóa tiềm năng trung bình là các loại đất phát sinh trên các đá trầm tích lục nguyên, đá biến chất và macma xâm nhập hoặc phun trào bazan tuổi Pliocen - Pleistocen sớm $\left(\mathrm{N}_{2}-\mathrm{Q}_{1}{ }^{1}\right)$, đất có tầng dày từ $50-<100 \mathrm{~cm}$, trên địa hình có độ dốc trung bình dưới $15^{\circ}$. Hoặc các khu vực có độ dài mùa khô dưới 4 tháng và số tháng kiệt nhỏ hơn 2 tháng. 
Bảng 6: Phân cấp độ dốc cho đánh giá thoái hóa đất tiềm năng

\begin{tabular}{|c|c|c|c|}
\hline STT & Cấp độ dốc & Ký hiệu & Mức độ thoái hóa \\
\hline 1 & Độ dốc từ $0-8^{\circ}$ & I & Yếu \\
\hline 2 & Độ dốc từ $8-15^{\circ}$ & II & Trung bình \\
\hline 3 & Độ dốc từ $15-25^{\circ}$ & III & Mạnh \\
\hline 4 & Độ dốc $>25^{\circ}$ & IV & Rất mạnh \\
\hline
\end{tabular}

Bảng 7: Phân cấp độ cao địa hình cho đánh giá thoái hóa đất tiềm năng

\begin{tabular}{|c|c|c|c|}
\hline STT & Độ cao địa hình & Ký hiệu & Mức độ thoái hóa \\
\hline 1 & Độ cao $<500 \mathrm{~m}$ & I & Yếu \\
\hline 2 & Độ cao $500-1.000 \mathrm{~m}$ & II & Trung bình \\
\hline 3 & Độ cao $1.000-1.500 \mathrm{~m}$ & III & Mạnh \\
\hline 4 & Độ cao $>1.500 \mathrm{~m}$ & IV & Rất mạnh \\
\hline
\end{tabular}

Bảng 8: Phân cấp mức độ khô hạn cho đánh giá thoái hóa đất tiềm năng

\begin{tabular}{|c|l|c|c|}
\hline STT & \multicolumn{1}{|c|}{ Mức độ khô hạn } & Ký hiệu & Mức độ thoái hóa \\
\hline 1 & $\begin{array}{l}\text { Khu vực có độ dài mùa khô } \leq 3 \text { tháng và không có tháng } \\
\text { kiệt }\end{array}$ & I & Yếu \\
\hline 2 & $\begin{array}{l}\text { Khu vực có độ dài mùa khô } 3 \text { - } 4 \text { tháng và có số tháng kiệt } \\
1 \text { tháng }\end{array}$ & II & Trung bình \\
\hline 3 & $\begin{array}{l}\text { Khu vực có độ dài mùa khô } 4 \text { tháng và có số tháng kiệt } 2 \\
\text { tháng }\end{array}$ & III & Mạnh \\
\hline 4 & $\begin{array}{l}\text { Khu vực có độ dài mùa khô } 4 \text { tháng và có số tháng kiệt 3 } \\
\text { tháng }\end{array}$ & IV & Rất mạnh \\
\hline
\end{tabular}


Bảng 9: Chỉ tiêu mật độ sông suối cho đánh giá thoái hóa đất tiềm năng

\begin{tabular}{|c|c|c|c|}
\hline STT & Mật độ sông suối $\left(\mathbf{k m} / \mathbf{k m}^{2}\right)$ & Ký hiệu & Mức độ thoái hóa \\
\hline 1 & $<0,5$ & I & Yếu \\
\hline 2 & $0,5-1,0$ & II & Trung bình \\
\hline 3 & $1,0-1,5$ & III & Mạnh \\
\hline 4 & $>1,5$ & IV & Rất mạnh \\
\hline
\end{tabular}

Bảng 10: Phân cấp chỉ tiêu xói mòn tiềm năng cho đánh giá thoái hóa tiềm năng

\begin{tabular}{|c|c|c|c|}
\hline STT & Mức độ xói mòn tiềm năng (tấn/ha/năm) & Ký hiệu & Mức độ thoái hóa \\
\hline 1 & $<100$ & I & Yếu \\
\hline 2 & $100-500$ & II & Trung bình \\
\hline 3 & $500-1.000$ & III & Mạnh \\
\hline 4 & $>1.000$ & IV & Rất mạnh \\
\hline
\end{tabular}

- Tiềm năng thoái hóa mạnh (TN3): Diện tích cấp thoái hóa tiềm năng mạnh khu vực nghiên cứu có khoảng 1.159.188,9 ha (chiếm 21,2\%). Trong đó, tỉnh Gia Lai tập trung lớn nhất khoảng $363.754,9$ ha; tiếp đến Lâm Đồng 350.260,5 ha; Kon Tum có $313.645,5$ ha; Đắk Lắk có $126.061,8$ ha; Đắk Nông có $5.466,2$ ha. Trên bản đồ cho thấy, các đơn vị thoái hóa tiềm năng mạnh là các loại đất có tầng dày từ $30-50 \mathrm{~cm}$, phát triển trên phun trào bazan tuổi Pliocen - Pleistocen sớm $\left(\mathrm{N}_{2}-\mathrm{Q}_{1}{ }^{1}\right)$ có tầng laterit. Hoặc những khu vực có độ dài mùa khô từ 3 - 5 tháng và số tháng khô kiệt dưới 3 tháng.

- Tiềm năng thoái hóa rất mạnh (TN4): Thoái hóa tiềm năng rất mạnh vùng Tây
Nguyên có khoảng $716.707,4$ ha (chiếm 13,1\%). Trong đó, Gia Lai chiếm 278.625,3 ha; Lâm Đồng có $152.687,8$ ha; Kon Tum có 150.469,3 ha; Đắk Nông có $100.096,6$ ha và Đắk Lắk có $34.828,4$ ha. Kết quả thể hiện trên bản đồ cũng cho thấy, các khu vực có thoái hóa tiềm năng rất mạnh phân bố tập trung ở rìa cao nguyên Buôn Ma Thuột; cao nguyên Kon Hà Nừng; cao nguyên Lâm Viên và những nơi xuất hiện bôxit của cao nguyên Đắk Nông - Đắk Mil. Các loại đất này phát triển trên loại đá phun trào bazan tuổi Pliocen - Pleistocen sớm $\left(\mathrm{N}_{2}-\mathrm{Q}_{1}{ }^{1}\right)$. Các loại đất xói mòn trơ sỏi đá hoặc các loại đất xám tầng rất mỏng $(<30 \mathrm{~cm})$ cũng thuộc mức thoái hóa tiềm năng rất mạnh. (Xem bảng 11, hình 2) 
Bảng 11: Quy mô các cấp thoái hóa đất tiềm năng vùng Tây Nguyên

\begin{tabular}{|l|c|c|c|c|c|}
\hline \multirow{2}{*}{ Tỉnh } & \multicolumn{4}{|c|}{ Diện tích các cấp thoái hóa đất tiềm năng (ha) } & \multirow{2}{*}{ Tổng (ha) } \\
\cline { 2 - 5 } & TN1 & TN2 & TN3 & TN4 & \\
\hline Kon Tum & $237.291,2$ & $267.554,7$ & $313.645,5$ & $150.469,3$ & $968.960,6$ \\
\hline Gia Lai & $357.386,7$ & $553.926,4$ & $363.754,9$ & $278.625,3$ & $1.553 .693,3$ \\
\hline Đắk Lắk & $456.997,4$ & $694.649,4$ & $126.061,8$ & $34.828,4$ & $1.312 .537,0$ \\
\hline Đắk Nông & $259.157,7$ & $286.841,0$ & $5.466,2$ & $100.096,6$ & $651.561,5$ \\
\hline Lâm Đồng & $218.099,9$ & $256.171,4$ & $350.260,5$ & $152.687,8$ & $977.219,6$ \\
\hline Toàn vùng & $\mathbf{1 . 5 2 8 . 9 3 3 , 0}$ & $\mathbf{2 . 0 5 9 . 1 4 2 , 8}$ & $\mathbf{1 . 1 5 9 . 1 8 8 , 9}$ & $\mathbf{7 1 6 . 7 0 7 , 4}$ & $\mathbf{5 . 4 6 3 . 9 7 2 , 0}$ \\
\hline
\end{tabular}

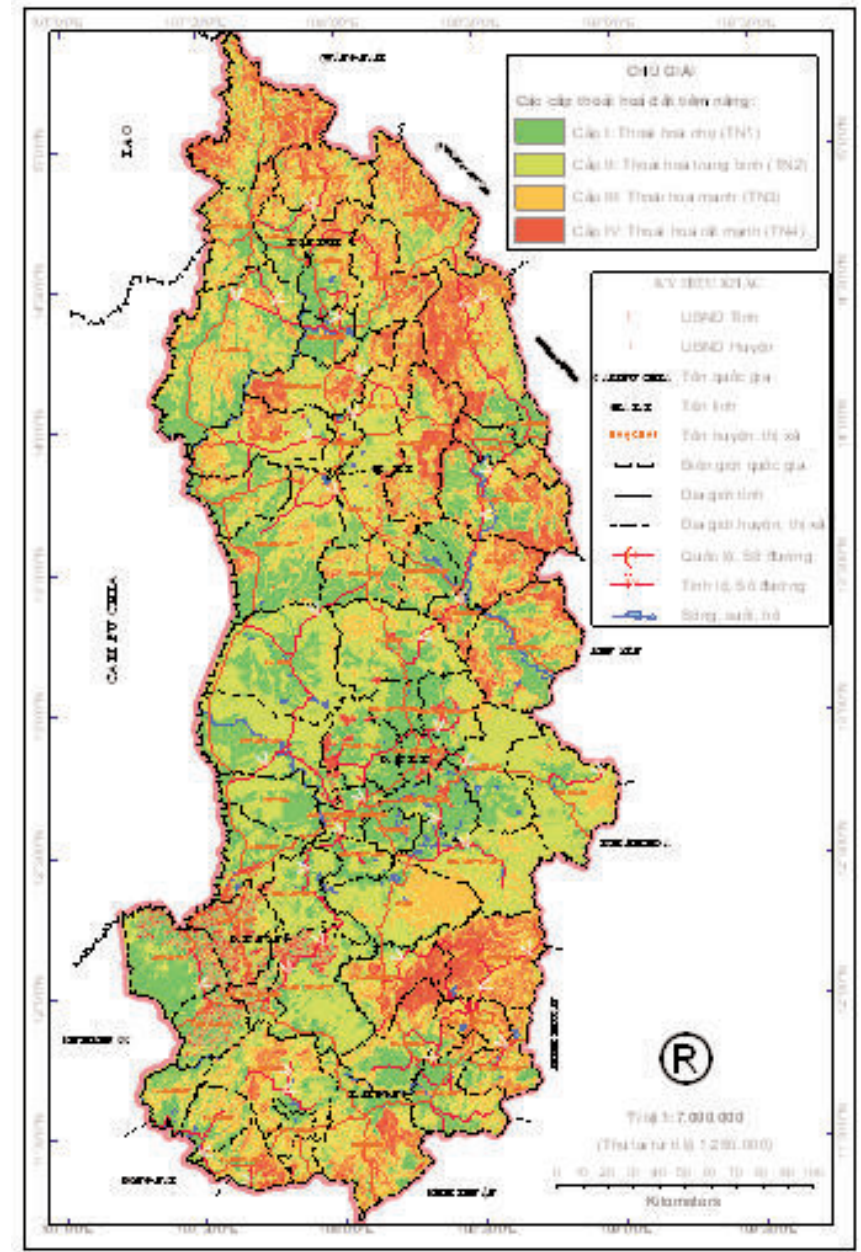

Hình 2: Bản đồ thoái hóa đất tiềm năng vùng Tây Nguyên 


\section{Kết luận}

Tiếp cận quan điểm địa lý tổng hợp phân tích và đánh giá các yếu tố tiền đề thoái hóa đất tiềm năng cho phép lựa chọn được 9 chỉ tiêu của 4 tiêu chỉ (địa hình; đá mẹ - vỏ phong hóa và thổ nhưỡng, khí hậu và thủy văn, xói mòn tiềm năng) để thành lập bản đồ thoái hóa đất vùng Tây Nguyên tỷ lệ 1:250.000 với sự hỗ trợ đắc lực của công nghệ GIS bằng các thuật toán khác nhau. Trong nghiên cứu này đã sử dụng thuật toán trung bình cộng trong phần mềm ArcGIS. Với khả năng linh hoạt và tính ưu việt trong phân tích không gian, công nghệ GIS hoàn toàn có thể ứng dụng để thành lập các bản đồ chuyên đề chỉ số đầu vào, cũng như tích hợp các bản đồ này để thành lập bản đồ thoái hóa đất tiềm năng trong thời gian ngắn, cho kết quả có độ tin cây. Quy trình kỹ thuật của phương pháp này có thể áp dụng đối với các vùng sinh thái khác ở Việt Nam.

Bản đồ thoái hóa đất tiềm năng vùng Tây Nguyên tỷ lệ 1:250.000 có ý nghĩa và thực tiễn trong bối cảnh các quá trình thoái hóa đất đã và đang xảy ra với quy mô lớn, cường độ mạnh. Kết quả nghiên cứu cung cấp thông tin toàn cảnh về tiềm năng thoái hóa đất ở các mức độ khác nhau, làm cơ sở tham khảo quan trọng cho công tác lập quy hoạch sử dụng đất và bố trí cây trồng hợp lý, nhằm hạn chế được các quá trình thoái hóa đất. Đồng thời, có thể áp dụng các biện pháp canh tác thích hợp trên từng đơn vị đất có tiềm năng thoái hóa khác nhau. $O$

\section{Tài liệu tham khảo}

[1]. Lưu Thế Anh (2012). Nghiên cứu xây dựng bản đồ thoái hóa đất tỉnh Đắk Lắk và Đắk Nông phục vụ sử dụng bền vững tài nguyên đất. Luận án tiến sỹ chuyên ngành Địa lý Tài nguyên và Môi trường. Lữu trữ tại Viện Địa lý.

[2]. Chính phủ Việt Nam (2006). Chương trình hành động quốc gia chống sa mạc hóa giai đoạn 2006 - 2010 và định hướng đến năm 2020. Ban hành kèm theo Quyết định số 204/2006/QĐ-TTg ngày 2/9/2006 của Thủ tướng Chính phủ.

[3]. Nguyễn Đình Kỳ và nnk (1987). Nghiên cứu tổng hợp đất bazan thoái hoá vùng Tây Nguyên làm cơ sở khoa học sử dụng hợp lý chúng. Báo cáo khoa học Chương trình cấp nhà nước 48-09, Trung tâm Địa lý Tài nguyên, Hà Nội.

[4]. Nguyễn Đình Kỳ, Lưu Thế Anh (2005). Nghiên cứu thoái hoá đất trên bazan Tây Nguyên phục vụ đề xuất giải pháp tổng thể sử dụng hợp lý và bảo vệ đất. Báo cáo Đề tài nhánh thuộc Đề tài cấp nhà nước mã số KC.08.26.

[5]. ADB (2008). Land degradation in Central Asia. Revised draft final report. Central Asian countries initiative for land management multicountry partnership framework support project.

[6]. FAO (2002). Land degradation assessment in dryland - LADA project. World soil resources report 97, Rome, Italy.

[7]. Moe Myint and Pema Thinley (2006). Mapping potential land egradation in Bhutan. ASPRS 2006 Annual Conference, Nevada.

[8]. Oldeman, L.R. (1988). Guidelines for general assessment of the status of humaninduced soil degradation. Global assessment of soil degradation (GLASOD). International Soil Reference and Information Centre, Wageningen.

[9]. Oldeman, L.R., Hakkeling, R.T.A. and Sombroek, W.G. (1990 - 1991). World map of the status of human-induced soil degradation.

[10]. Taimi Sofia Kapalanga (2008). A review of land degradation assessment methods. Land restoration Training Programe. Golabeb Training and Research Centre, Namibia.

(Xem tiếp trang 64) 